\title{
Microbiological quality of kitchens sponges used in university student dormitories
}

\author{
Tareq M. Osaili ${ }^{1,2,3^{*}}$, Reyad S. Obaid ${ }^{1,2}$, Klaithem Alowais ${ }^{1}$, Rawan Almahmood ${ }^{1}$, Moza Almansoori ${ }^{1}$, \\ Noora Alayadhi', Najla Alowais ${ }^{1}$, Klaithem Waheed ${ }^{1}$, Dinesh Kumar Dhanasekaran², Anas A. Al-Nabulsi' \\ Mutamed Ayyash ${ }^{4}$ and Stephen J. Forsythe ${ }^{5}$
}

\begin{abstract}
Background: Kitchen sponges are a major source of cross-contamination as they can transfer foodborne pathogens, infectious agents and spoilage causing microorganisms to food contact surfaces. Several studies have revealed that university students adopt poor practices regarding food safety, hygiene, and the handling of kitchen cleaning equipment.

Methods: A total of fifty kitchen sponges were collected along with a questionnaire addressing social demographics and kitchen sponge usage by students living at the University of Sharjah dormitories. The effect of storage ( 3 and 10 days) on the microbial population of kitchen sponges at room temperature $\left(21^{\circ} \mathrm{C}\right)$ was assessed. Enterobacteriaceae isolated from sponges were identified and their antibiotic resistance determined.

Results: Student responses revealed that kitchen sponges used to clean food contact surfaces were also used to clean the oven (32\%), sink (26\%), refrigerator (10\%), and to clean spills on the floor (4\%). Kitchen sponges contained high counts of mesophilic aerobic bacteria $\left(7.9 \log _{10} / \mathrm{cm}^{3}\right)$, coliform $\left(7.2 \log _{10} / \mathrm{cm}^{3}\right)$, Enterobacteriaceae $\left(7.3 \log _{10} /\right.$ $\mathrm{cm}^{3}$ ) and yeasts and molds $\left(7.0 \log _{10} / \mathrm{cm}^{3}\right)$. After storage of the sponges at room temperature $\left(21^{\circ} \mathrm{C}\right)$ for 3 and 10 days, the number of mesophilic aerobic bacteria, coliform, Enterobacteriaceae and yeasts and molds decreased by 0.4 and $1.3 \log _{10} / \mathrm{cm}^{3}, 0.7$ and $1.4 \log _{10} / \mathrm{cm}^{3}, 0.4$ and $1.1 \log _{10} / \mathrm{cm}^{3}$, and 0.6 and $1.3 \log _{10} / \mathrm{cm}^{3}$, respectively. The most frequently isolated Enterobacteriaceae were Enterobacter cloacae (56\%) and Klebsiella oxytoca (16\%). All E. cloacae isolates were resistant to amoxicillin, cefalotin, cefoxitin and cefuroxime axetil.

Conclusions: This study showed that students living in dormitories lacked good hygienic practices and were at increased risk of food poisoning. Kitchen sponges were highly contaminated with potentially pathogenic bacteria which could be transferred from the general kitchen environment to food contact surfaces and consequently lead to food contamination.
\end{abstract}

Keywords: Sponges, Kitchen, Cleaning, Dormitories, Storage, Enterobacteriaceae, Antibiotic resistance

\section{Background}

Kitchen sponges are one of the main cleaning tools used to clean kitchen utensils and surfaces such as kitchen

\footnotetext{
* Correspondence: tosaili@sharjah.ac.ae; tosaili@just.edu.jo

'Department of Clinical Nutrition and Dietetics, College of Health Sciences, University of Sharjah, P. O. Box 27272, Sharjah, United Arab Emirates

${ }^{2}$ Research Institute for Medical and Health Sciences, University of Sharjah, P. O. Box 27272, Sharjah, United Arab Emirates

Full list of author information is available at the end of the article
}

utensils cutting boards, sinks, oven tops and refrigerators $[1,2]$. However, during cleaning food residues may adhere to the sponge surface and damp sites such as sink areas can act as further microbial reservoirs that can contaminate the sponges during their use [3]. Subsequent poor handling, storage or improper disinfection of kitchen sponges will lead to further microbial growth at room temperature [4]. Consequently, kitchen sponges

(c) The Author(s). 2020 Open Access This article is licensed under a Creative Commons Attribution 4.0 International License, which permits use, sharing, adaptation, distribution and reproduction in any medium or format, as long as you give appropriate credit to the original author(s) and the source, provide a link to the Creative Commons licence, and indicate if changes were made. The images or other third party material in this article are included in the article's Creative Commons licence, unless indicated otherwise in a credit line to the material. If material is not included in the article's Creative Commons licence and your intended use is not permitted by statutory regulation or exceeds the permitted use, you will need to obtain permission directly from the copyright holder. To view a copy of this licence, visit http://creativecommons.org/licenses/by/4.0/ The Creative Commons Public Domain Dedication waiver (http://creativecommons.org/publicdomain/zero/1.0/) applies to the data made available in this article, unless otherwise stated in a credit line to the data. 
are a major source of cross-contamination as they can transmit foodborne pathogens, infectious agents and spoilage causing microorganisms to food contact surfaces $[5,6]$.

A study conducted in 10 kitchens in the United States of America found that 33 and $67 \%$ of the tested sponges were positive for Escherichia coli and fecal coliforms, respectively [7]. Furthermore, Enriquez et al. [8] found that $15.4 \%$ of sponge samples taken from households were contaminated with Salmonella spp. Further studies have shown that kitchen sponges collected from domestic kitchens were contaminated with Campylobacter spp., Enterobacter cloacae, E. coli, Klebsiella spp., Proteus spp., Salmonella spp., Acinetobacter, Moraxella, and Staphylococcus spp. [9-14]. In similar studies, kitchen sponges were found to harbor high counts of aerobic mesophilic bacteria, coliforms, Enterobacteriaceae, yeasts and molds due to poor kitchen sponge sanitization practices [4, 8, 15-18].

Coliforms are a general group of bacteria within the Enterobacteriaceae which have been used as indicator microorganisms for hygiene monitoring purposes. Coliforms can be found in the kitchen due to inadequate disinfection procedures, inappropriate sanitary and hygienic practices, and contamination by raw products, and cross-contamination from contaminated food [19]. In a hygiene study of a household, kitchen sponges had the second highest load coliforms, the highest being drain traps [20].

Beside the significant health, social, and economic impact of microbial infections [21], the increase in antibiotic resistant bacteria is a serious threat to human health which may result in incurable infections and fatality in both developed and developing regions [22]. Enterobacteriaceae are potential causes of serious infections and are increasingly resistant to antibiotics. A major concern with Enterobacteriaceae is the production of ESBLs leading to multidrug resistance and creating pan-resistant bacterial strains [23]. ESBL encoding Enterobacteriaceae are usually found in the hospital setting but are becoming prevalent in the community as well [24]. Widespread recovery of multidrug-resistant Enterobacteriaceae from chicken meat would lead to restricted treatment options if infections occur [21].

Several studies of university students have shown that they adopt poor practices regarding food safety, hygiene, and the handling of kitchen cleaning tools such as sponges [25-27]. Consequently, they increase their risk to foodborne illnesses [25-27]. The aims of this study were to (i) explore the microbial quality and usage of kitchens sponges used at the University of Sharjah student dormitories, (ii) assess the effect of storage on the microbial populations in the sponges, and (iii) identify any Enterobacteriaceae isolated from sponges and determine their antibiotic resistance profiles.

\section{Methods \\ Sample collection and kitchen sponge usage questionnaire}

The researchers visited the female dormitories (two locations) at the University of Sharjah twice a week on different days between 8:00 am-12:00 pm randomly without prior notification and explained the objectives of study to the students who were available in the rooms during the visits. Usually, 1-2 students stay in each room which consists of a bedroom, small kitchen and bathroom. Students who agreed to participate in the study signed a consent form. Fifty students from the two locations agreed to participate in the study.

Kitchen sponges used in the kitchens were collected from students who agreed to participate in the study ( $n=50)$ using sterilized forceps. Only one sponge was used in each room; students share the same sponge in the two-student rooms. The temperature of the rooms in the dormitories were maintained at $21^{\circ} \mathrm{C}$ and there were no windows near to the kitchens. The sponges were kept on the sinks in the kitchens and were not exposed to direct sunlight. The collected sponges were put separately into sterilized plastic bags and transferred within $30 \mathrm{~min}$ to Nutrition and Food laboratory (Research Institute for Medical and Health Sciences, University of Sharjah) in an ice box for analysis. In addition, a questionnaire designed by the investigators for this study was completed by the participants $(n=50)$. The questionnaire was consisted of two parts; the first part included questions on their socio-demographic profile, whereas the second part included questions on their kitchen sponge usage (available in the supplementary files).

\section{Sample preparation for analysis}

The materials of the kitchen sponges collected from students' dormitories were polyester (soft yellow side) and polyurethane (abrasive side). Each sponge was coded and cut into three parts using a sterile knife. The average dimensions of the sponge parts were $6.6 \mathrm{~cm} \times 3.2 \mathrm{~cm} \times$ $3.3 \mathrm{~cm}$. The first part of the sponge was analyzed microbiologically within $1 \mathrm{~h}$ from receipt. The second and third parts of the sponge were kept separately at ambient temperature $\left(21^{\circ} \mathrm{C} \pm 1\right)$ and a relative humidity of $59 \% \pm$ 2 for 3 and 10 days in a sterile un-covered plastic container.

\section{Weight and water activity measurements}

The weight and water activity $\left(\mathrm{a}_{\mathrm{w}}\right)$ (Labmaster aw, Novasina AG, Switzerland) of the inner and external parts of the sponge samples (W $2 \mathrm{~cm} \times \mathrm{H} 1.5 \mathrm{~cm}$ ) at time 0,3 and 10 days before microbiological analysis of the 
samples were measured. The average value of the readings was used.

\section{Microbiological analysis}

The sponge samples were added to $100 \mathrm{ml}$ of $0.1 \%$ peptone water (HiMedia Laboratories, India) in a sterilized stomacher bag, and put in the mixing machine (blender EASYMIX, bioMérieux, France) for $2 \mathrm{~min}$. After that, decimal dilutions were made and 1 or $0.1 \mathrm{ml}$ from appropriate dilution was plated on duplicate on violet red bile glucose agar (VRBGA, HiMedia) for enumeration of Enterobacteriaceae, violet red bile agar (VRBA, HiMedia) for enumeration of coliforms, total plate count agar (TPCA, HiMedia) for enumeration of mesophilic aerobic bacteria, and Sabouraud dextrose agar (SDA, Mast Group Ltd., UK) for enumeration of yeasts and molds, by using the pour plate technique. VRBGA and TPCA were incubated aerobically for $48 \mathrm{~h}$ at $32{ }^{\circ} \mathrm{C}$, while VRBA was kept aerobically at $37^{\circ} \mathrm{C}$ for $48 \mathrm{~h}$. The SDA plates were kept aerobically at $21^{\circ} \mathrm{C}$ for 5 days. Unused sponges $(n=3)$ representing the same brands of the sponge samples used in the study were purchased from local markets and used as negative controls.

\section{Identification of Enterobacteriaceae isolates}

One typical Enterobacteriaceae colony representing each sponge sample (pink or purple color colonies) was picked from VRBGA and inoculated into $10 \mathrm{ml}$ tryptone soya broth (HiMedia). The tubes were mixed and incubated in $32{ }^{\circ} \mathrm{C}$ for $24 \mathrm{~h}$ before being streaked on nutrient agar HiMedia) and incubated for $24 \mathrm{~h}$ at $32^{\circ} \mathrm{C}$. Isolates were identified using the VITEK 2 GN ID card (bioMerieux, Marcy-l'Étoile, France) as according to the manufacturer's instructions.

\section{Antibiotic resistance test}

The antibiotic susceptibility of Enterobacteriaceae isolates was determined using the VITEK 2 (bioMerieux) using the Gram-negative susceptibility card (AST-N215). The card tested the susceptibility of the isolates to ampicillin, amoxicillin, piperacillin/tazobactam, cefalotin, cefuroxime, cefuroxime axetil, cefoxitin, cefpodoxime, cefotaxime, ceftazidime, imipenem, meropenem, gentamicin, tobramycin, ciprofloxacin, norfloxacin, tetracycline, nitrofurantoin, and trimethoprim/sulfamethoxazole.

\section{Statistical analysis}

The data collected from the questionnaire, as well as the identification and antibiotic resistance profile of the Enterobacteriaceae isolates were analyzed by using IBM SPSS Statistics 25.0 software for descriptive statistical mean, percentage, standard deviation, and frequency. The differences in the microbial populations in the sponge samples during storage were tested with one-way analysis of variance (ANOVA) and post-hoc analysis by Tukey. Statistical significance at $P$-value $<0.05$ was considered to be a significant level.

\section{Results}

The results of the questionnaire study (Table 1) showed that more than half $(66 \%)$ of the participants were medical students (medicine, dentistry, pharmacy and health sciences colleges). The respondents were mostly from the first and fourth year, while fifth- and second- year students were the least. Two thirds of the respondents stated that the sponges were used by two students, less than one third (30\%) were used by one student, and a small percentage $(4 \%)$ by three students. More than half the participants $(58 \%)$ had used the sponge for less than one month, $32 \%$ used the sponge for two months, and $10 \%$ had used the sponge for more than 2 months. Seventy percent of participants do not sanitize their sponges. The main use of the sponges was for cleaning utensils (94\%) and cooking pots (90\%). About two thirds of the collected sponges were used to clean cutting boards. One third of the collected sponge samples (32\%) were used to clean the oven, while 26 and $30 \%$ of the collected sponges are used to clean sink and surfaces around the sink, respectively. A very low percentage of 4 and $10 \%$ of the students clean spills on kitchen floor and interior/exterior surfaces of the refrigerator using the same sponge that is used to clean food utensils.

The mean weight of sponges $(n=6)$ declined during storage; $6.22 \mathrm{~g}( \pm 1.74)$ in 0 day, $2.72 \mathrm{~g}( \pm 0.54)$ in 3 days, and $2.59 \mathrm{~g}( \pm 0.57)$ in 10 days. The mean $\mathrm{a}_{\mathrm{w}}$ value of sponges was $0.93( \pm 0.18)$ in 0 day. This decreased to $0.57( \pm 0.16)$ and $0.55( \pm 0.06)$ after 3 and 10 days of storage.

The viable counts of mesophilic aerobic bacteria, yeasts and molds, Enterobacteriaceae, and coliforms in sponge samples during storage at room temperature $\left(21^{\circ} \mathrm{C}\right)$ for 0,3 and 10 days are shown in Fig. 1 . The populations of the tested microorganisms in the sponge samples decreased as the storage time increased. There was no significant difference between the populations of the microorganisms from sponge samples at time 0 and after 3 days of storage, while significant differences were found on day 10 of storage. Mesophilic aerobic bacteria counts decreased after 3 and 10 days of storage by 0.4 and $1.3 \log _{10} / \mathrm{cm}^{3}$ respectively. Yeasts and molds populations decreased after 3 and 10 days of storage by 0.6 and $1.3 \log _{10} / \mathrm{cm}^{3}$ respectively. Enterobacteriaceae populations decreased after 3 and 10 days of storage by 0.4 and $1.1 \log _{10} / \mathrm{cm}^{3}$ respectively. Similarly, coliform populations decreased after 3 and 10 days of storage by 0.7 and $1.4 \log _{10} / \mathrm{cm}^{3}$ respectively. For the negative control sample, mesophilic aerobic bacteria and yeasts and molds populations were 2.46 and $1.80 \log _{10} / \mathrm{cm}^{3}$ respectively. 
Table 1 Characteristics and responses of students living in university dormitories to questions on kitchen sponge usage

\begin{tabular}{|c|c|c|}
\hline Questions & Frequency & Percentage \\
\hline \multicolumn{3}{|l|}{ College } \\
\hline Medical & 33 & $66 \%$ \\
\hline Nonmedical & 17 & $34 \%$ \\
\hline \multicolumn{3}{|l|}{ Year } \\
\hline First & 18 & $36 \%$ \\
\hline Second & 4 & $8 \%$ \\
\hline Third & 10 & $20 \%$ \\
\hline Fourth & 13 & $26 \%$ \\
\hline Fifth & 5 & $10 \%$ \\
\hline \multicolumn{3}{|c|}{ How many students are using the sponge? } \\
\hline One & 15 & $30 \%$ \\
\hline Two & 33 & $66 \%$ \\
\hline Three & 2 & $4 \%$ \\
\hline \multicolumn{3}{|c|}{ How long have you been using this sponge? } \\
\hline Less than one month & 29 & $58 \%$ \\
\hline Two months & 16 & $32 \%$ \\
\hline Three months & 2 & $4 \%$ \\
\hline More than three months & 3 & $6 \%$ \\
\hline \multicolumn{3}{|c|}{ Do you clean or sanitize the sponge? } \\
\hline Yes & 15 & $30 \%$ \\
\hline No & 35 & $70 \%$ \\
\hline \multicolumn{3}{|c|}{ Do you use this sponge in cleaning plates and silver utensils? } \\
\hline Yes & 47 & $94 \%$ \\
\hline No & 3 & $6 \%$ \\
\hline \multicolumn{3}{|c|}{ Do you use this sponge in cleaning cooking pot? } \\
\hline Yes & 45 & $90 \%$ \\
\hline No & 5 & $10 \%$ \\
\hline \multicolumn{3}{|c|}{ Do you use this sponge in cleaning cutting boards? } \\
\hline Yes & 32 & $64 \%$ \\
\hline No & 18 & $36 \%$ \\
\hline \multicolumn{3}{|c|}{ Do you use this sponge in cleaning stove? } \\
\hline Yes & 16 & $32 \%$ \\
\hline No & 34 & $68 \%$ \\
\hline \multicolumn{3}{|c|}{ Do you use this sponge in cleaning sink? } \\
\hline Yes & 13 & $26 \%$ \\
\hline No & 37 & $74 \%$ \\
\hline \multicolumn{3}{|c|}{ Do you use this sponge in cleaning surfaces beside the sink? } \\
\hline Yes & 15 & $30 \%$ \\
\hline No & 35 & $70 \%$ \\
\hline \multicolumn{3}{|c|}{ Do you use this sponge in cleaning spills on the kitchen floor? } \\
\hline Yes & 2 & $4 \%$ \\
\hline No & 48 & $96 \%$ \\
\hline \multicolumn{3}{|c|}{ Do you use this sponge in cleaning interior and exterior surfaces of the refrigerator? } \\
\hline Yes & 5 & $10 \%$ \\
\hline No & 45 & $90 \%$ \\
\hline
\end{tabular}




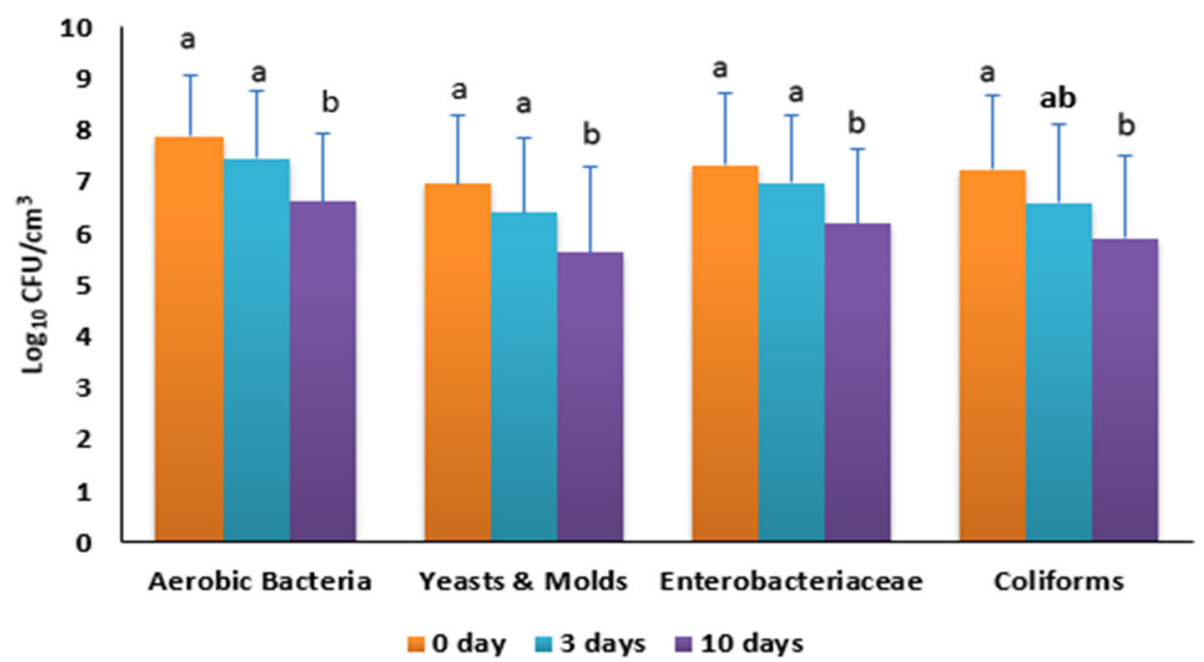

Fig. 1 Microbial populations $\left(\log 10 \mathrm{CFU} / \mathrm{cm}^{3}\right)$ in kitchen sponge samples collected from student dormitories during storage at room temperature $\left(21^{\circ} \mathrm{C}\right)$ for 0,3 and 10 days. Different letters per tested group indicate significant differences among the microbial populations $(P<0.05)$

No Enterobacteriaceae or coliforms were detected in the samples.

E. cloacae were the most prevalent (56\%) Enterobacteriaceae isolated (Table 2). K. oxytoca was the next most frequently isolated organism (16\%), with $E$. aerogenes and $K$. pneumoniae being recovered from $6 \%$ of the samples. Raoultella ornithinolytica and Serratia marcescens were less frequently isolated (4\%). Other Enterobacteriaceae were Lelliottia amnigena, Pantoea spp., Kluyvera intermedia and Cedecea davisae (2\%).

Table 3 shows the antibiotic resistance of the Enterobacteriaceae isolates. The antibiograms varied from no resistance, to strains that showed resistance to 9 antibiotics. All E. cloacae isolates $(n=28)$ were resistant to amoxicillin, cefalotin, cefuroxime, cefoxitin and cefuroxime axetil. Only one isolate was resistant to cefpodoxime. E. aerogenes was resistant to ampicillin, amoxicillin, cefalotin, cefuroxime, cefoxitin, cefuroxime axetil and cefpodoxime. The $C$. davisae isolate was resistant to ampicillin, amoxicillin, cefalotin and cefoxitin. Klu. intermedia was susceptible to all antibiotics. All K. pneumoniae isolates $(n=3)$ showed high resistance to ampicillin and one isolate showed a resistance to amoxicillin. $K$. oxytoca is resistant to ampicillin, amoxicillin, cefalotin, cefuroxime, cefuroxime axetil, cefoxitin, cefpodoxime, cefotaxime, ceftazidime. L. amnigena and Pantoea spp. showed resistance to amoxicillin, cefalotin and cefoxitin, while resistance to cefuroxime and cefuroxime axetil was observed in L. amnigena. $R$. ornithinolytica and $S$. marcescens were resistant to amoxicillin, cefalotin, and cefoxitin also, $R$. ornithinolytica is resistant to ampicillin and $S$. marcescens resistant to cefuroxime axetil.

\section{Discussion}

Good hygienic practices in the kitchen should include the separation of raw from ready to eat food and ensure work surfaces and utensils are clean to reduce the transfer of foodborne pathogens as a result of crosscontamination. Disposable wipes are a suitable alternative, but there may be financial reasons for using reusable sponges or cloths. The use of sponge and their microbial contamination reflects the food safety practices of students. The results of the current study showed that students have insufficient knowledge on the proper use of reusable kitchen sponges as they reported using them for multiple purposes. Cleaning the refrigerator and sink with the same sponges that are used to clean food contact surfaces is the probable reason for the high microbial load of the sponges. A previous study reported that the sink area harbored one of the highest

Table 2 Identification of Enterobacteriaceae isolates from kitchen sponge samples

\begin{tabular}{llll}
\hline Microorganisms & Frequency & Percentage & Probability \\
\hline Cedeceadavisae & 1 & $2.0 \%$ & $92 \%$ \\
Enterobacter aerogenes & 3 & $6.0 \%$ & $89-99 \%$ \\
Enterobacter cloacae & 28 & $56.0 \%$ & $89-99 \%$ \\
Klebsiella oxytoca & 8 & $16.0 \%$ & $95-99 \%$ \\
Klebsiella pneumoniae & 3 & $6.0 \%$ & $92-99 \%$ \\
Kluyvera intermedia & 1 & $2.0 \%$ & $88 \%$ \\
Lelliottia amnigena & 1 & $2.0 \%$ & $91 \%$ \\
Pantoea spp & 1 & $2.0 \%$ & $98 \%$ \\
Raoultella ornithinolytica & 2 & $4.0 \%$ & $94-95 \%$ \\
Serratia marcescens & 2 & $4.0 \%$ & $91-99 \%$ \\
Total & 50 & $100 \%$ & \\
\hline
\end{tabular}




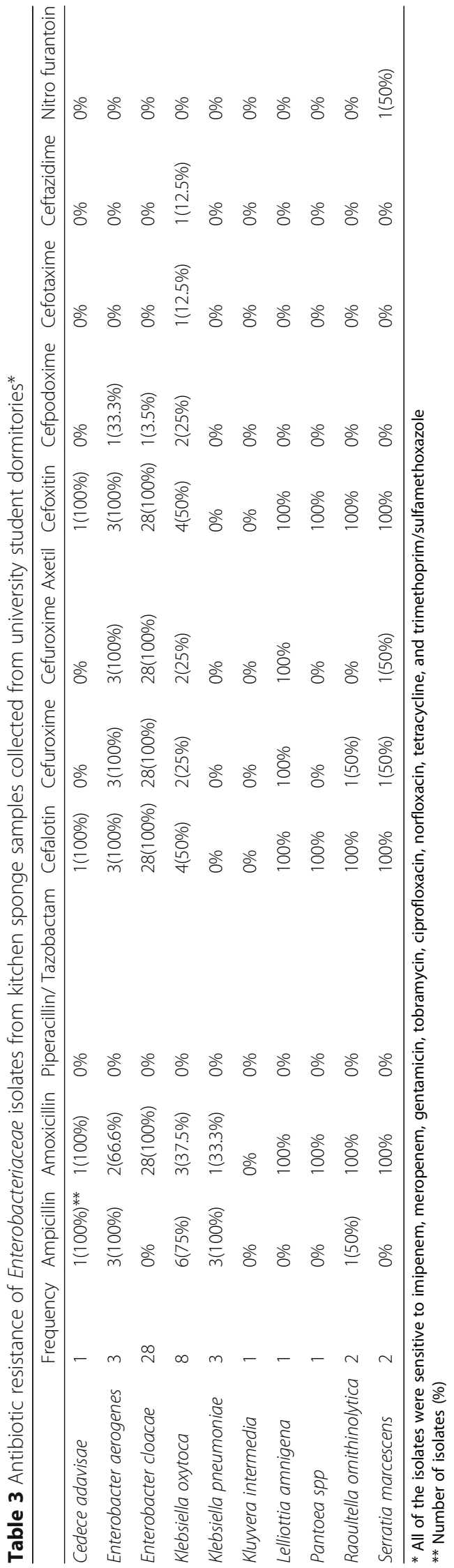


levels of microbial contamination, including coliform, fecal coliform and Enterobacteriaceae [25].

The student practices increase the risk of crosscontamination with pathogenic organisms (environmental and foodborne) being transferred to food contact surfaces such as utensils and then on to ready to eat food, leading to infection. Previous studies conducted among university students have also shown that students had poor food safety knowledge on cross-contamination [27, 28].

The time intervals chosen to store sponges (3 and 10 days) was to mimic the length of student absence for weekends ( 3 days) or study break (10 days). The decrease in mesophilic aerobic bacteria, yeasts and molds, Enterobacteriaceae and coliform counts was due to the storage of sponges at room temperature $\left(21^{\circ} \mathrm{C}\right)$ leading to the lack of moisture for any further microbial survival/ growth.

A number of the Enterobacteriaceae isolated are recognized bacterial pathogens (Table 2). E. aerogenes is associated with nosocomial infections of immunocompromised patients $[29,30]$. E. cloacae can cause opportunistic infection, such as meningitis [31]. It is one of the predominant bacteria isolated from domestic kitchens and student sponge samples [3, 5, 32]. $K$. oxytoca, second highest frequency isolate in this study, has previously been isolated from domestic kitchen sponges [5] and leafy green vegetables [33]. This bacterium can cause septicemia, pneumonia and urinary tract infection [34]. K. pneumoniae, can cause serious community-acquired pneumonia [35], and has been isolated from meat and meat contact surfaces [36], leafy green vegetables [33] as well as kitchen sponges [5]. The pathogenicity of $R$. ornithinolytica is uncertain but it has been associated with fish and causes scombroid syndrome [37]. The symptoms of which includes vomiting and flushing [38]. S. marcescens has been isolated from cooked refrigerated pork meat and can cause pneumonia and urinary tract infection $[39,40]$. Infection can be acquired through ingestion of contaminated food [41]. $L$. amnigena is considered an indicator of food contamination [42, 43]. E. cloacae, K. pneumoniaa, and Pantoea spp. have been isolated from leafy green vegetables [33, 44] which could explain their recovery from sponge used with cutting board. Pantoea spp. is mainly an environmental organism and can cause urinary tract infection and diarrhea [45]. C. davisae and Klu. intermedia are mainly present in respiratory tract $[33,46]$. Kluyvera sp. are found in environmental sources such as food, water, flies and sink [47].

The emergence of multidrug-resistant Enterobacteriaceae is a major concern to human health. In the present study, the antibiograms of the Enterobacteriaceae isolates showed that all $E$. cloacae isolates $(n=28)$ were resistant to amoxicillin, cefalotin, cefuroxime, cefoxitin and cefuroxime axetil while only one isolate was resistant to cefpodoxime. Similar to our findings, E. cloacae isolates from healthy broilers were reported to be resistant to amoxicillin [48] and those from green leafy vegetables were resistant to cephalothin, cefuroroxime, cefoxitin, amipicillin, and amoxicillin-clavulanate [49]. The increasing antibiotic resistance of pathogenic bacteria is a major public health issue as that will increase foodborne illnesses and narrow treatment choices [50].

\section{Conclusion}

In conclusion, female students live in dormitories at the University of Sharjah showed a lack of general knowledge regarding good hygienic practices. Kitchen sponges which were primarily for cleaning food contact surfaces, were often used for other general purposes and kept for prolonged periods of time. Leaving the sponges at room temperature for a few days did not reduce the microbial load of the sponges. These sponges were colonized by potentially pathogenic bacteria, which encoded for various antibiotic resistances. Students need to be reminded of good hygienic practices in order to reduce the risk of contaminating ready to eat food from raw foods, and the kitchen environment including the floor. This study has some potential limitations; the sample size was small and the study was conducted with female students as the data were collected by females who were not allowed to enter males dormitories; thus, further research is needed to include more students from both genders from other universities.

\section{Supplementary information}

Supplementary information accompanies this paper at https://doi.org/10. 1186/s12889-020-09452-4.

Additional file 1. Questionnaire on the use of the kitchen sponge at the dormitories. The file contains the questions used in the questionnaire.

\section{Abbreviations}

ESBLs: Extended-Spectrum $\beta$-lactamases

\section{Acknowledgments \\ The authors thank College of Health Sciences and the students who} participated in the study.

Authors' contributions

$\mathrm{TO}, \mathrm{RS}$ are the main investigator and responsible for the study design and writing of the manuscript. KA, RA, MA, NA1, NA2, KW reviewed the literature and conducted the lab work. DD supervised the lab work and analysis the data. AA, MA, SF contributed to the editing and approved the manuscript. All authors read and approved the final version of the manuscript.

\section{Funding}

Not applicable.

Availability of data and materials

The datasets used during the present study are available from the first author on reasonable request. 


\section{Ethics approval and consent to participate}

The ethical approval of this study was waived by Research and Ethics Committee (REC) at the University of Sharjah and written consent was obtained from all participants.

\section{Consent for publication}

Not applicable.

\section{Competing interests}

The authors declare that they have no competing interests.

\section{Author details}

'Department of Clinical Nutrition and Dietetics, College of Health Sciences, University of Sharjah, P. O. Box 27272, Sharjah, United Arab Emirates. ${ }^{2}$ Research Institute for Medical and Health Sciences, University of Sharjah, P. O. Box 27272, Sharjah, United Arab Emirates. ${ }^{3}$ Department of Nutrition and Food Technology, Faculty of Agriculture, Jordan University of Science and Technology, P.O. Box 3030, Irbid 22110, Jordan. ${ }^{4}$ Department of Food, Nutrition and Health, College of Food and Agriculture, United Arab Emirates University (UAEU), Al Ain, Abu Dhabi, United Arab Emirates.

${ }^{5}$ Foodmicrobe.com, Adams Hill, Keyworth, Nottingham NG12 5GY, UK.

Received: 15 July 2020 Accepted: 26 August 2020

Published online: 31 August 2020

\section{References}

1. Beumer RR, Kusumaningrum H. Kitchen hygiene in daily life. Int Biodete Biodegr. 2003;51:299-302.

2. Ikawa J, Rossen J. Reducing bacteria in household sponges. J Environ Health. 1999:62:18-22.

3. Wolde T, Bacha K. Microbiological safety of kitchen sponges used in food establishments. Int J Food Sci. 2016;1659784.

4. Speirs JP, Anderson A, Anderson JG. A study of microbial content of domestic kitchen. Int J Environ Health Res. 1995;5:109-22.

5. Marotta S, Giarratana F, Calvagna A, Ziino G, Giuffrida A, Panebianco A Study on microbial communities in domestic kitchen sponges: evidence of Cronobacter sakazakii and extended Spectrum Beta lactamase (ESBL) producing bacteria. Ital J Food Saf. 2018;7:7672.

6. Obi CN, Ndukwu CC. Microbiological examination of household kitchen sponges from three communities in Ikwuano L.G.a, Umuahia, Abia state Nigeria. Br Microbiol Res J. 2016;11:1-9.

7. Josephson KL, Rubino JR, Pepper IL. Characterization and quantification of bacterial pathogens and indicator organisms in household kitchens with and without the use of a disinfectant cleaner. J Appl Microbiol. 1997;87: $737-50$

8. Enriquez CE, Enriquez-Gordillo R, Kennedy DI, Gerba CP. Bacteriological survey of used cellulose sponges and dishcloths from domestic kitchens. Dairy Food Environ Sanit. 1997:17:20-4.

9. Adiga I, Shobha KL, Mustaffa MB, Bismi NHB, Yusof NHB, Ibrahim NL, Norazira NB. Bacterial contamination in the kitchen: could it be pathogenic? Webmed Central Med Edu. 2012;3:WMC003256.

10. Alwakeel SS. Bacterial and Aspergillus spp. contamination of domestic kitchens in Riyadh, Saudi Arabia. Saudi J Biol Sci. 2007;14:1-6.

11. Cardinale M, Kaiser D, Lueders T, Schnell S, Egert M. Microbiome analysis and confocal microscopy of used kitchen sponges reveal massive colonization by Acinetobacter, Moraxella and Chryseobacterium species. Sci Rep. 2017;7:5791.

12. Erdoğrul Ö, Erbilir F. Microorganisms in kitchen sponges. Inter J Food Saf. 2005;6:17-22.

13. Humphrey TJ, Martin KW, Slader J, Durham K. Campylobacter spp. in the kitchen: spread and persistence. J Appl Microbiol. 2001;90:115-20.

14. Marshall BM, Robleto E, Dumont T, Levy SB. The frequency of antibioticresistant bacteria in homes differing in their use of surface antibacterial agents. Current Microbiol. 2012;65:407-15.

15. Chaidez C, Gerba CP. Bacteriological analysis of cellulose sponges and loofahs in domestic kitchens from a developing country. Dairy Food Environ Sanit. 2000;20:834-7.

16. Rusin P, Orosz-Coughlin P, Gerba C. Reduction of faecal coliform, coliform, and heterotrophic plate count bacteria in the household kitchen and bathroom by disinfection with hypochlorite cleaners. J Appl Microbiol. 1998; 85:819-28.
17. Scott E, Bloomfield SF, Barlow CG. An investigation of microbial contamination in the home. J Hyg Camb. 1982;89:279-93.

18. Sharma M, Eastridge J, Mudd C. Effective household disinfection methods of kitchen sponges. Food Control. 2009;20:310-3.

19. Rossi E, Scapin D, Grando W, Tondo E. Microbiological contamination, and disinfection procedures of kitchen sponges used in food services. Food Nutr Sci. 2012;3:975-80.

20. Ojima M, Toshima Y, Koya E, Ara K, Tokuda H, Kawai S, Kasuga F, Ueda N. Hygiene measures considering actual distributions of microorganisms in Japanese households. J Appl Microbiol. 2002;93:800-9.

21. Yulistiani R, Praseptiangga D, Supyani SRD, Shirakawa T. Prevalence of antibiotic-resistance Enterobacteriaceae strains isolated from chicken meat at traditional markets in Surabaya, Indonesia IOP Conference Series. Mat Sci Eng. 2017;193:012007.

22. Wellington EMH, Boxall ABA, Cross P, Feil EJ, Gaze WH, Hawkey PM, Johnson AS, Jones DL, Lee NM, Otten W, Thomas CM, Williams AP. The role of the natural environment in the emergence of antibiotic resistance in gramnegative bacteria. Lancet Infect Dis. 2013;13:155-65.

23. Paterson DL. Resistance in gram-negative bacteria: Enterobacteriaceae. Am J Med. 2006;1 19:520-8.

24. Kassakian SZ, Mermel LA. Changing epidemiology of infections due to extended spectrum beta-lactamase producing bacteria. Antimicrob Resist In. 2014;3:9.

25. Hassan K, El-Bagoury M. The domestic student kitchen: a microbiological Hazard? J Pure Appl Microbiol. 2017;11:1687-93.

26. Miko BA, Cohen B, Conway L, Gilman A, Seward SL, Larson E. Determinants of personal and household hygiene among college students in New York city. Am J Infect Control. 2011;40:940-5.

27. Osaili T, Obeidat B, Abu Jamous D, Bawadi H. Food safety knowledge and practices among college female students in north of Jordan. Food Control. 2010;22:269-76

28. Lazou T, Georgiadis M, Pentieva K, McKevitt A, lossifidou E. Food safety knowledge and food-handling practices of Greek university students: a questionnaire-based survey. Food Control. 2012;28:400-11.

29. Davin-Regli A, Pagès J. Enterobacter aerogenes and Enterobacter cloacae; versatile bacterial pathogens confronting antibiotic treatment. Front Microbiol. 2015:6:392.

30. Mammeri H, Laurans G, Eveillard M, Castelain S, Eb F. Coexistence of SHV-4and TEM-24-producing Enterobacter aerogenes strains before a large outbreak of TEM-24-producing strains in a French hospital. J Clin Microbiol. 2001;39:2184-90.

31. Keller R, Pedroso MZ, Ritchmann R, Silva RM. Occurrence of virulenceassociated properties in Enterobacter cloacae. Infect Immun. 1998;66:645-9.

32. Hassan K, Elbagoury M. Genetic identification of predominant bacteria isolated from student kitchen. J Pure Appl Microbiol. 2018;12:277-80.

33. Perkins S, Beckett T, Bump C. Cedecea davisae bacteremia. J Clin Microbiol. 1986;24:675-6.

34. Singh L, Cariappa M, Kaur M. Klebsiella oxytoca: an emerging pathogen? Med J Armed Forces India. 2016;72(Suppl 1):S59-61.

35. Vading $M$, Nauclér $P$, Kalin $M$, Giske CG. Invasive infection caused by Klebsiella pneumoniae is a disease affecting patients with high comorbidity and associated with high long-term mortality. PLoS One. 2018;13:e0195258.

36. Stiles ME, Ng LK. Enterobacteriaceae associated with meats and meat handling. Appl Environ Microbiol. 1981;41:867-72.

37. Lin CS, Tsai HC, Lin CM, Huang CY, Kung HF, Tsai YH. Histamine content and histamine-forming bacteria in mahi-mahi (Coryphaena hippurus) fillets and dried products. Food Control. 2014;42:165-71.

38. Hajjar R, Schwenter F, Su S, Gasse M, Sebajang H. Community-acquired infection to Raoultella ornithinolytica presenting as appendicitis and shock in a healthy individual. J Surg Case Rep. 2018:5:1-3.

39. Ziino G, Giuffrida A, Giufrè N, Greco V, Panebianco A. Survey on Serratia marcescens isolated from cooked refrigerated pork meat. Ind Aliment. 2010;49:15-31.

40. Mahlen SD. Serratia infections: from military experiments to current practice. Clin Microbiol Rev. 2011;24:755-91.

41. Farmer JJ III, Davis B, Hickman F, Presley DB, Bodey G, Negut M, Bobo RA. Detection of Serratia outbreaks in hospital. Lancet. 1976;308:455-9.

42. Liu S, Tang Y, Wang D, Lin N, Zhou J. Identification and characterization of a new Enterobacter onion bulb decay caused by Lelliottia amnigena in China. Appl Microbiol Open Access. 2016;2:114.

43. Fontán MCG, Lorenzo JM, Parada A, Franco I, Carballo J. Microbiological characteristics of "androlla", a Spanish traditional pork sausage. Food Microbiol. 2007;24:52-8. 
44. Osaili T, Alaboudi A, Al-Quran H, Al-Nabulsi A. Decontamination and survival of Enterobacteriaceae on shredded iceberg lettuce during storage. Food Microbiol. 2018;73:129-36.

45. AbdAlhussen LS, Darweesh MF. Prevalence and antibiotic susceptibility patterns of Pantoea spp. isolated form clinical and environmental sources in Iraq. Int J ChemTech Res. 2016;9:430-7.

46. Farmer J, Fanning G, Huntley-Carter G, Holmes B, Hickman F, Richard C, Brenner DJ. Kluyvera, a new (redefined) genus in the family

Enterobacteriaceae: identification of Kluyvera ascorbata sp. nov. and Kluyvera cryocrescens sp. nov. in clinical specimens. J Clin Microbiol. 1981;13:919-33.

47. Steele J, Aggarwal G. Infections due to Kluyvera species ASCP check sample MB 10-4. Am J Clin Pathol. 2010;53:39-50.

48. Moawad A, Hotzel A, Neubauer H, Ehricht R, Monecke S, Tomaso H, Hafez $M$, Uwe R, Hosny A. Antimicrobial resistance in Enterobacteriaceae from healthy broilers in Egypt: emergence of colistin-resistant and extendedspectrum $\beta$-lactamase-producing Escherichia coli. Gut Pathog. 2018;10:39.

49. Al-Holy M, Osaili T, El-sayed S, Alshammari E, Ashankyty I. Microbiological quality of leafy green vegetables sold in the local market of Saudi Arabia. Ital J Food Sci. 2013;25:446-52.

50. Anderson AD, Nelson JM, Rossiter S, Angulo FJ. Public health consequences of use of antimicrobial agents in food animals in the United States. Microb Drug Resist. 2003;9:373-9.

\section{Publisher's Note}

Springer Nature remains neutral with regard to jurisdictional claims in published maps and institutional affiliations.

Ready to submit your research? Choose BMC and benefit from:

- fast, convenient online submission

- thorough peer review by experienced researchers in your field

- rapid publication on acceptance

- support for research data, including large and complex data types

- gold Open Access which fosters wider collaboration and increased citations

- maximum visibility for your research: over $100 \mathrm{M}$ website views per year

At BMC, research is always in progress.

Learn more biomedcentral.com/submissions 